$\longrightarrow$ -

(日本化学会誌, 1989, (2), p. 299 301)

\title{
方形波ポーラログラフィーによるリボフラビンの 吸着ストリッピングボルタンメトリー
}

(1988 年 7 月 28 日受理)

澤 本 博 道*・桂木 浩 文

\section{1 緒言}

環境試料中の重金属の分析には，ヨーロッパやアメリカなどで はアマルガム生成反応を濃縮に利用するアノーディックストリッ ピングボルタンメトリーがよく用いられている。アマルガム生成 反応のかわりに吸着を濃縮に用いると，有機物の高感度分析が可 能であり，すでに多くの有機物の定量が；報告されている11 7)。 著者はリボフラビンの吸着ストリッピングボルタンメトリーに関 する基礎的検討を報告した8)。今回は方形波ポーラログラフィー を用いて感度向上と実試料中のリボフラビンの定量を試みた。

\section{2 実験}

吊下水銀滴電極は Metrohm 社製 E 410 型を用いた。その表面 積は $1.41 \times 10^{-2} \mathrm{~cm}^{2}$ であった。用いた方形波ポーラグラフは扶 桑製作所製 311 型と 333 型であった。アノーディックストリッ ピングに拉いては，ロイコフラビンが吸着する電位 $(-0.65 \mathrm{~V}$ vs. SCE) において溶液をかきまぜながら濃縮した。1 分間休止 期間を取った後, 電位を正に掃引して酸化電流を測定した。カソ ーディックストリッピングに拈いては, 吸着浱縮は通常 $0 \mathrm{~V}$ で行 なっだ。

\section{3 結果と考察}

前回 ${ }^{8)}$ の報告においては，支持電解質には， $0.1 \mathrm{M}$ 酶酸アンモ ニウム $\left(\mathrm{mol} \cdot \mathrm{dm}^{-3}\right)$ を用いた。支持電解質の種類と浱度は吸着に も䉓荷授受反応にも大きな影響を与えるので，今回は種々の支持 電解質を用いて検討した。酢酸ナトリウム, 塩化アンモニウム,

高知大学教育学部, 780 高知市曙町

1) J.Wang, "Stripping Analysis", VCH Publishers, Florida (1985) p. 61.

2) A.G. Fogg, A. A. Barros, J. O. Cabral, Analyst, 111, 831(1986).

3) E. Palecek, P. Boublikova, F. Jelen, Anal. Chim. Acta, 187, 99(1986).

4) M. Kopanica, V.Stara, J. Electroanal. Chem. Interfacial Electrochem., 214, 115(1986).

5) R. Kalvoda, ibid., 214, 191(1986).

6) J. M. F. Alvarlz, A. C. Garcia, A. J. M. Ordieres, ibid., 225, 241(1987).

7) J. Wang, M.S. Lin, V. Villa, Analyst, 112, 1303 (1987).

8) H.Sawamoto, J. Electroanal. Chem. Interfacial Electrochem., 186, 257(1985).
塩化カリウム, 酢酸アンモニウムなどを用いて検討した結果, $0.1 \mathrm{M}$ 酢酸ナトリウムが最高のピークを示した。酢酸ナトリウム の浱度の影響を検討すると， $0.1 \mathrm{M}$ が最高であった。カソーディ ックストリッピングです同様であったので, 以下支持電解質とし ては，0.1M 临酸ナトリウムを用いた。

湄縮電位の影響を検討すると（図 1), 前回 ${ }^{81}$ はアノーディック ストリッピングの感度がカソーディックストリッピングよりも優 れていたが，今回はカソーディックストリッピングの感度が 20

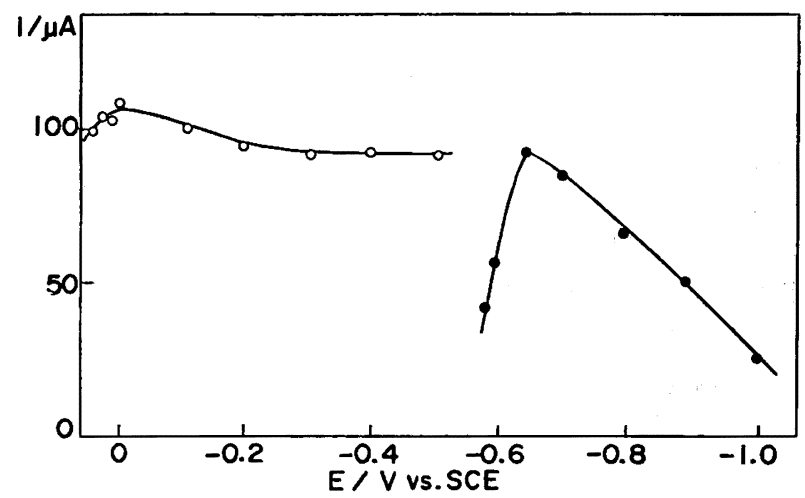

Fig. 1 Effect of preconcentration potential on peak height

Concentration of riboflavin in $0.1 \mathrm{M}$ sodium acetate : $0.1 \mu \mathrm{M}$; preconcentration time : $5 \mathrm{~min}$; (O) : Anodic stripping ; $(\mathrm{O})$ : Cathodic stripping

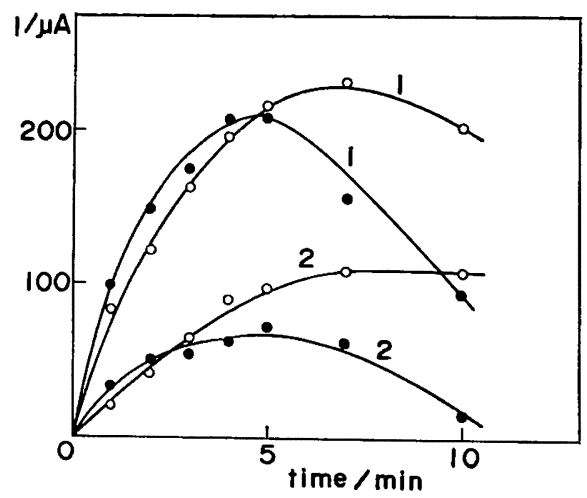

Fig. 2 Effect of preconcentration time on peak height Concentration of riboflavin in $0.1 \mathrm{M}$ sodium acetate : (1) 0.2 ; (2) $0.1 \mu \mathrm{M}$; (O) : Anodic stripping ; (O) : Cathodic stripping 
倍上昇したためにアノーディックストリッピングよりもカンー ディックストリッピンクの感度がよくなった。最適淟縮電位は $-0.65 \mathrm{~V}$ (アノーディックストリッピング)，0V(カソーディッ クストリッピング) であった。濃縮時間の影響を調べると（図 2)，5分まではピーク電流は增大したが，その後濃縮時間が增す

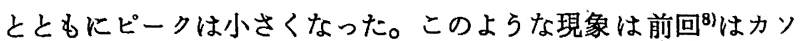
ーディックストリッピングでは見られたが，アノーディックスト リッピングではみられなかった。通常四着平衡のために，濃縮時 間が一定以上になると，ピーク電流が一定になる場合が多い。し かし，ここでは濃縮時間の增加とともに逆にピークが小さくなる といら異常現象が見られる。リボフラビンやロイコフラビンの四 着で，蹯水基の方が水銀電極の方にあり，酸化・還元を受けると ころは親水基の方にあるので，電極から遠く，あまりきちんと吸 着すると，自己妨害止のために，電荷授受反応が阻害されるため であると考えられる。そこで5分を最適としは。

電位掃引速度の影響を検討すると， $5 \mathrm{mV} / \mathrm{s}$ までは掃引速度の 增加とともにピーク電流も大きくなるが， $5 \mathrm{mV} / \mathrm{s}$ を越光ると逆 にピークは低くなるので, $5 \mathrm{mV} / \mathrm{s}$ を最適とした。交流ポーラログ ラフィーの理論10)では交流波振幅に比例してピークは大きくな る。方形波振幅の增加とともに $50 \mathrm{mV}$ まではほほ惊線的にピー ク波高は增大するが，100 mV を越えると逆に減少し，またピー クの幅が広くなってくるので， $50 \mathrm{mV}$ を最適とした。交流ボーラ ログラフィーでは通常 10〜30 mVぐらいを用いることが多いが， 感度を上げるために $50 \mathrm{mV}$ を最適とした。ピーク波高は方形波 周波数に正比例した。これによると周波数が大きいほどピーク電 流は大きくなるが，基底電流も増加するので， $S / N$ 比を考学る と，むしろ低艒波が望ましく，25 Hz を最適とした。测定時刻の 值を大きくするとリボフラビンのピークも，支持電解質のみの電 流值も小さくなる。 $S / N$ 比を考光ると， Sample Time 3 が適当で

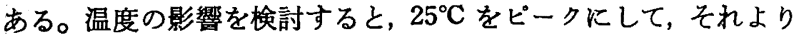
も高くても低くてもピークは減少したので $25^{\circ} \mathrm{C}$ を最適とした。

以上，アノーディックストリッピンクについて求めた最適条件 により求めた検量線は $100 \mathrm{nM}$ までほぼ直線である。相対標準偏 差は 4. $3 \%(50 \mathrm{nM})$ で，検出限界は $1 \mathrm{nM}$ であった。妨害物質 の影響を調べると, $20 \mu \mathrm{M} \mathrm{Co}_{1}^{2+}, 1 \mu \mathrm{M} \mathrm{Cd}^{2+}, 1 \mu \mathrm{M} \mathrm{Pb}^{2+}, 0.1$

9) E. Laviron, J. Electroanal. Chem. Interfacial Electrochem., 52, 355(1974).

10) A. J. Bard, L. R. Faulkner, "Electrochemical Methods", John Wiley \& Sons, New York (1980) p. 333.

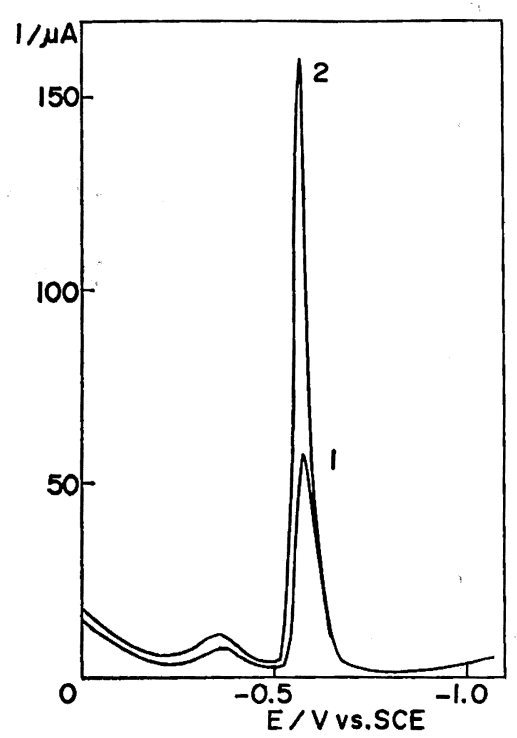

Fig. 3 Cathodic adsorptive stripping voltammogram of riboflavin in a soft drink

$1: 0.01 \%$ soft drink, $2: 1+0.1 \mu \mathrm{M}$ riboflavin in $0.1 \mathrm{M}$ sodium acetate

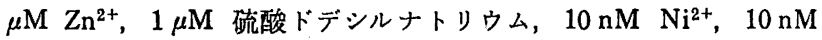
$\mathrm{Cu}^{2+}$ はリボフラビンのピークに影響を与えなかった。

カソーディックストリッピングに执いて，最適条件（濃縮電位 0V 以外はアノーディックストリッピングと同じ）による検量線 は $100 \mathrm{nM}$ まで直線であった。相対標準偏差は $2.2 \%(50 \mathrm{nM})$ で，険出限界は $0.5 \mathrm{nM}$ であった。 $1 \mu \mathrm{M}$ 硫酸ドデシルナトリウ ム, $1 \mu \mathrm{M} \mathrm{Cd}^{2+}, 1 \mu \mathrm{M} \mathrm{Pb}^{2+}, 0.1 \mu \mathrm{M} \mathrm{Zn}^{2+}, 20 \mu \mathrm{M} \mathrm{Co}^{2+}, 10 \mathrm{nM}$ $\mathrm{Ni}^{2+}$ は $50 \mathrm{nM}$ のリボフラビンの定量を妨害しなかった。

実試料として清涼领料水を分析した。清涼领料水 $2.5 \mu \mathrm{l}$ を 25 $\mathrm{m} l$ のメスフラスコにとり，これに支持電解質を加えて測定した。 その結果を図 3 に示す。清涼领料水は種々の物質を含むが, 10000 倍に希釈されているので，そのまま測定することができ る。この結果, この清涼领料水は $58 \mathrm{mM}$ のリボフラビンを含む ことが明らかになった（標準添加法で定量）。本法の開発により， 微量ではない物質も，希釈することにより，妨害物質の影響を受 けずに定量することができた。 


\section{Adsorptive Stripping Voltammetry of Riboflavin by Square Wave Polarography}

Hiromiti $\mathrm{S}_{\mathrm{Awamoto}}$ and Hirofumi Katsuragi

Faculty of Education, Kochi University; Akebono-cho, Kochi-shi 780 Japan

Two stripping methods of analysis of riboflavin were proposed by square wave polarography in which preconcentration is achieved by the adsorption of riboflavin or its reduced form. The supporting electrolyte used was $0.1 \mathrm{M}$ ammonium acetate, the preconcentration potentials were $-0.65 \mathrm{~V}$ (anodic stripping) and $0 \mathrm{~V}$ (cathodic stripping). Preconcentration time was $5 \mathrm{~min}$, and scan rate was $5 \mathrm{mV} / \mathrm{s}$. Square wave amplitude and frequency were $50 \mathrm{mV}$ and $25 \mathrm{~Hz}$, respectively. Sample time was 3 in 10 and temperature was $25^{\circ} \mathrm{C}$. Caliblation curves for anodic and cathodic stripping were linear up to $100 \mathrm{nM}$. The detection limits were $1 \mathrm{nM}$ (anodic stripping) and $0.5 \mathrm{nM}$ (cathodic stripping). Riboflavin in a soft drink was determined by the proposed cathodic stripping method. 